\title{
A Preliminary Link between Hydroxylated Metabolites of Polychlorinated Biphenyls and Free Thyroxin in Humans
}

\author{
Eveline Dirinck ${ }^{1, *}$, Alin C. Dirtu ${ }^{2}$, Govindan Malarvannan ${ }^{2}$, Adrian Covaci ${ }^{2}$, \\ Philippe G. Jorens ${ }^{3}$ and Luc F. Van Gaal ${ }^{1}$ \\ 1 Department of Endocrinology, Diabetology and Metabolism, Antwerp University Hospital, \\ University of Antwerp, Wilrijkstraat 10, Edegem 2650, Belgium; luc.van.gaal@uza.be \\ 2 Toxicology Centre, University of Antwerp, Wilrijk 2610, Belgium; alindirtu@yahoo.com (A.C.D.); \\ malarvannan.govindan@uantwerpen.be (G.M.); adrian.covaci@uantwerpen.be (A.C.) \\ 3 Department of Clinical Pharmacology, Antwerp University Hospital, University of Antwerp, Edegem 2650, \\ Belgium; philippe.jorens@uza.be \\ * Correspondence: eveline.dirinck@uza.be; Tel.: +32-38213278 \\ Academic Editor: Huixiao Hong \\ Received: 26 January 2016; Accepted: 11 April 2016; Published: 13 April 2016
}

\begin{abstract}
Background: Polychlorinated biphenyls (PCBs) and their hydroxylated metabolites (HO-PCBs) interfere with thyroid hormone action both in vitro and in vivo. However, epidemiologic studies on the link between PCB exposure and thyroid function have yielded discordant results, while very few data are available for HO-PCBs. Objectives: Our study aimed at investigating the relationship between clinically available markers of thyroid metabolism and serum levels of both PCBs and HO-PCBs. Subjects and Methods: In a group of 180 subjects, thyroid-stimulating hormone (TSH) and free thyroxin (fT4), 29 PCBs (expressed both in lipid weight and in wet weight) and $18 \mathrm{HO}-\mathrm{PCBs}$ were measured in serum. Results: In regression models, adjusted for gender, age, current smoking behavior, BMI and total lipid levels, serum levels of 3HO-PCB118 and 3HO-PCB180, and PCB95 $5_{1 w}, P C B 99_{1 w}$ and PCB149 $9_{1 w}$ were independent, significant predictors of fT4. A stepwise, multiple regression with gender, age, current smoking behavior, BMI and total lipid levels and all five previously identified significant compounds retained age, BMI, PCB95 ${ }_{1 \mathrm{w}}, \mathrm{PCB} 99_{\mathrm{lw}}$ and $3 \mathrm{HO}-\mathrm{PCB} 180$ as significant predictors of fT4. TSH levels were not predicted by serum levels of any of the PCBs or HO-PCBs. Conclusions: Our study indicates that in vivo, circulating fT4 levels can be linked to serum levels of several PCBs and hydroxylated PCB metabolites.
\end{abstract}

Keywords: polychlorinated biphenyls; hydroxylated polychlorinated biphenyls; thyroid function; human; endocrine disrupters

\section{Introduction}

The endocrine system plays an essential and pervasive role in the regulation of whole body homeostasis. The thyroid system is a classic neuro-endocrine axis, comprising a feedback system between the hypothalamus releasing thyrotropin-releasing hormone (TRH), the pituitary gland releasing thyroid-stimulating hormone (TSH) and the thyroid gland producing and secreting $\mathrm{T} 4$ and, to a lesser extent, T3. In the circulation, both hormones are protein bound (in humans to a high-affinity protein called TBG or thyroxine binding globulin) and less than 1\% of these hormones circulate as free-T3 (fT3) and free-T4 (fT4). The feedback among the hypothalamus, pituitary, and thyroid maintains blood levels of thyroid hormones within relatively narrow limits [1]. Thyroid hormones are key players in the control system of our metabolism, with, amongst others, a pivotal role in energy metabolism, heart rate, and emotional stability $[2,3]$. 
Thyroid function can be influenced and disrupted by both endogenous and exogenous factors. Some of these factors are not amendable. TSH tends to increase during the lifespan [4,5], and is influenced by gender [6]. Other elements are more modifiable. Several reports have linked active smoking to lower TSH levels [7-9], whereas the influence of BMI is not as uniform [10,11]. Finally, lipid levels may also be associated with TSH [12].

Several man-made chemicals are suspected to have thyroid-disrupting properties [13-15]. Amongst them are the polychlorinated biphenyls (PCBs), a group of organochlorine chemicals. Since they are very resistant to extreme temperature and pressure, they were widely used in capacitors, transformers, hydraulic fluids, lubricants and as plasticizers. More than 200 individual PCB congeners have been identified in commercial mixtures, whose chemical and toxicological properties are related to the number and position of the chlorine atoms. Despite the ban on their production in Europe since the 1970s, their ongoing use, chemical stability, resistance to degradation, and lipophilicity has lead to significant bioaccumulation in most compartments of the ecosystem and human tissues [16,17]. This bioaccumulation leads to an ongoing human exposure to PCBs through a variety of pathways, dietary intake being the most important [18].

PCBs are slowly metabolized by the human body [19]. The first phase of this biotransformation process is mediated by cytochrome $\mathrm{P} 450$ monooxygenase isozymes, resulting in hydroxylated PCB compounds (OH-PCBs), which are persistent too and are slowly eliminated [20]. Many OH-PCBs are retained in the blood bound to proteins and, as such, have the potential to exert toxic effects [20].

Given their structural resemblance to thyroxin [21], both PCBs and OH-PCBs are under scrutiny for their potential role in thyroid disruption. In animal studies, both circulating free thyroxin (fT4), as well as serum triiodothyronine (fT3) were significantly reduced after exposure to PCB mixtures or individual congeners [22-25]. Some animal studies report that serum thyroid-stimulating hormone (TSH) is elevated by PCBs in response to low fT4 [26], whereas others report essentially no effect of PCB exposure on serum TSH $[27,28]$.

Several studies have examined associations between PCB serum levels and thyroid hormones in humans. However, studies focusing on the link between hydroxylated PCB metabolites and thyroid function are scarce [29]. At present, taken into consideration the past and current exposure level in a Western population, thyroid function is considered a potential target for endocrine toxicity by persistent chemicals such as PCBs [30]. Our study aimed at investigating the relationship between serum levels of PCBs and, in particular, hydroxylated PCB metabolites, with clinically available markers of thyroid function in a group of normal weight, overweight and obese adults.

\section{Subjects and Methods}

\subsection{Study Population}

Participants were prospectively recruited when visiting the Department of Endocrinology of the Antwerp University Hospital between November 2009 and February 2012. All participants were Belgian citizens, living in the vicinity of the Antwerp University Hospital, and all were sampled in the same time frame. Participants contacted the department due to existing obesity or diabetes. Participants were eligible if they were 18 years or older, and were overweight or obese. Participants were not eligible for the study if they were under 18 years of age, had type 1 diabetes mellitus, were pregnant or suffered from active psychiatric illness. Occupational exposure to PCBs was ruled out by detailed questioning by the physician. Patients with occupational exposure were excluded from the study. Since TSH values are influenced by age, gender and possibly BMI, a control group of age- and gender-matched normal weight individuals was recruited for this study. This study was approved by the local Ethical Committee (Belgian Registry number B30020097009) and registered at clinicaltrials.gov (number NCT01778868). All participants provided their written informed consent. A total of 196 participants were included in the study. Sixteen out of 196 participants $(=8.2 \%)$ were excluded from further analyses, 15 participants due to the present use of thyroxin for hypothyroidism 
and one patient due to a significantly elevated TSH of $14.63 \mathrm{mU} / \mathrm{L}$. Two male patients were diagnosed with subclinical hypothyroidism (TSH 4.37 and $5.05 \mathrm{mU} / \mathrm{L}$ respectively). We did not detect subclinical hyperthyroidism. All other patients (123 women and $57 \mathrm{men}$ ) were in a euthyroid state.

\subsection{Thyroid Function}

Amongst all participants, history on thyroid disease was taken, and the use of current thyroid medication was recorded. Venous blood samples were obtained in the fasting state between 08.00 A.M. and 10.00 A.M. into sterile BD Vacutainer tubes. Thyroid Stimulating Hormone (TSH) and free Thyroxin (fT4) were measured using chemiluminescence Luminescence Oxygen Channeling Immunoassay (Dimension Vista, Siemens, Beersel, Belgium) at the hospital laboratory [31]. Reference values for TSH were $0.36-3.74 \mathrm{mU} / \mathrm{L}$, and 9.8-18.8 pmol/L for fT4. We opted to focus on the clinically relevant markers TSH and fT4, as recommended by an expert panel [32].

\subsection{Anthropometry}

Anthropometric measures were taken in the morning with individuals in a fasting state and undressed. Height was measured to the nearest $0.5 \mathrm{~cm}$; body weight was measured with a digital scale to the nearest $0.2 \mathrm{~kg}$. BMI was calculated as weight (expressed in $\mathrm{kg}$ ), divided by the square of the height (expressed in meters).

\subsection{Toxicological Analyses}

Serum samples (typically $4.5 \mathrm{~mL}$ ) were analyzed for 28 PCB congeners and 18 PCB metabolites according to the protocol described in detail by Dirtu et al. [33]. In short, solid-phase extraction (SPE) on OASIS HLB cartridges was used followed by fractionation on silica SPE cartridges topped with $0.5 \mathrm{~g}$ of acidified silicagel $\left(44 \% \mathrm{H}_{2} \mathrm{SO}_{4}, w / w\right)$. The first fraction was eluted with $n$-hexane and contained neutral compounds, such as PCBs. The phenolic fraction eluted as second with dichloromethane and included HO-PCBs. The second fraction was derivatized with trimethylsilyl diazomethane $(0.2 \mathrm{M}$ in $n$-hexane) for $30 \mathrm{~min}$ at $60{ }^{\circ} \mathrm{C}$. Both fractions evaporated to near dryness and reconstituted in iso-octane. The extracts were analyzed by gas chromatography coupled to mass spectrometry operated either in electron capture negative chemical ionization or electron impact mode depending on the sensitivity of the analytes. Further details on the analytical parameters and QA/QC protocols are given in Dirtu et al. [33].

PCB levels were expressed on a wet weight basis $\left(\mathrm{PCB}_{\mathrm{ww}}\right)$ and a lipid adjusted basis $\left(\mathrm{PCB}_{\mathrm{lw}}\right)$. All levels were added to create the sum of all PCBs ( $\Sigma$ PCBs). Total lipids were calculated using the formula: Total lipids $(\mathrm{g} / \mathrm{L})=$ total cholesterol $(\mathrm{g} / \mathrm{L}) \times 2.27+$ triglycerides $(\mathrm{g} / \mathrm{L})+0.62$ [34]. Total cholesterol and triglycerides were measured at the Antwerp University Hospital, using a validated method (Siemens Dimension Vista 1500 System, Beersel, Belgium). Levels below the method level of quantification (LOQ) were assigned a value of $\mathrm{DF} \times \mathrm{LOQ}$, with DF being the proportion (\%) of measurements with levels above the LOQ or the detection frequency [35].

\subsection{Statistical Analysis}

Statistical calculations were performed using SPSS, version 20.0 (SPSS Inc., Chicago, IL, USA). Normality of distribution was verified using the Kolmogorov-Smirnov test. All PCB and HO-PCB levels displayed a skewed distribution, which was transformable to normality after log transformation for most PCB and HO-PCB levels. TSH and fT4 were not normally distributed in our population, but were normalized after square root transformation and were used as such in the statistical analyses. Partial correlation analyses, using wet weight data and correcting for total lipids, were performed. To correct for multiple testing, a False Discovery Rate Correction Procedure was applied (with $q=0.05$ and $m=47$ ). Standard linear regression analyses were performed to assess the impact on fT4 and TSH levels. Residuals were normally distributed in all models. In the models, adjustments were made for gender, age, current smoking behavior (active versus non-smoker) and BMI, total lipids and 
a wet weight PCB serum level or PCB metabolite level. The analyses were repeated using a model containing gender, age, current smoking behavior, BMI and a lipid-adjusted PCB serum level. The same correction for multiple testing was applied (False Discovery Rate Correction Procedure with $q=0.05$ and $m=47$ ). After identification of significant contributors, these were inserted, together with gender, age, current smoking behavior, BMI and total lipids into a single forward stepwise regression analysis. A significance level of $p<0.05$ was accepted for all analyses.

\section{Results}

\subsection{Study Population}

The study population consisted of 123 women (68\%) and 57 men (32\%) with a mean age of $41 \pm 13$ years (Table 1). The population selected consists of both lean and obese subjects. There was no statistically significant difference in age or sex between obese participants and lean participants. Analyses were not restricted to an obese population, given the data from the literature that suggest that obese patients might have a higher TSH level within the euthyroid range, compared to their lean counterparts. This observation is, however, not repeated in all studies [11]. In our population, there is no significant difference in TSH levels between obese and lean participants. Given most patients with type 2 diabetes are obese, several articles report a high frequency of elevated TSH in type 2 diabetes [36]. In the present study there is no statistical difference in TSH level between participants with type 2 diabetes, normal glucose tolerance or prediabetes (data not shown).

Table 1. Clinical characteristics of 180 euthyroid study subjects.

\begin{tabular}{lcccc}
\hline Characteristics & No. & Percentage & Mean \pm SD & Range \\
\hline Gender & 123 & 68 & & \\
$\quad$ Female & 57 & 32 & & \\
$\quad$ Male & & & & \\
Smoking & 28 & 16 & & \\
$\quad$ Yes & 152 & 84 & $31 \pm 13$ & $18-84$ \\
No & 180 & & & \\
Age & 180 & & $1.66 \pm 0.5-62.3$ \\
BMI & & & $13.5 \pm 2.1$ & \\
\hline All subjects & 180 & & $1.74 \pm 0.77$ & $0.34-5.05$ \\
\hline TSH (mU/L) & 180 & & $13.5 \pm 1.9$ & $0.40-3.58$ \\
fT4 (pmol/L) & 123 & & & $9.3-19.3$ \\
Female subjects & 123 & & $1.51 \pm 0.84$ & $0.34-5.05$ \\
TSH (mU/L) * & 123 & & $13.4 \pm 2.4$ & $10.3-20.0$ \\
fT4 (pmol/L) & 57 & & & \\
Male subjects & 57 & & & \\
TSH (mU/L) * & 57 & & & \\
fT4 (pmol/L) & & & & \\
\hline
\end{tabular}

Legend: BMI = body mass index; ${ }^{*}$ Significant difference $(p<0.05)$ between female and male subjects, as assessed by Mann-Witney U test.

\subsection{Toxicological Analysis}

We detected all 28 PCB congeners and all 18 PCB metabolites in most of the subjects. Results on the exact levels are presented as supplementary information (Tables S1 and S2).

\subsection{Partial Correlation Analysis}

After correction for multiple testing, no significant partial correlations between TSH or fT4 on the one hand and $\mathrm{PCB}_{\mathrm{ww}}$ or HO-PCB serum levels on the other hand could be detected. 


\subsection{Regression Analysis for fT4}

The models using $\mathrm{PCB}_{\mathrm{lw}_{\mathrm{w}}}$ serum levels revealed a significant contribution to fT4 levels for $\mathrm{PCB}_{\mathrm{C}} 5_{\mathrm{lw}}$, $\mathrm{PCB} 9_{1 \mathrm{w}}$ and PCB149 ${ }_{\mathrm{lw}}$ (Table 2, for a complete overview of all models, please see Supplementary Table S3). The models using a PCB metabolite serum level indicated a significant contribution to fT4 levels for 3HO-PCB118 and 3HO-PCB180 (Table 2, for a complete overview of all models please see Supplementay Table S4). Using the previously identified statistically significant PCB serum levels and hydroxylated PCB metabolite serum levels in a single forward stepwise procedure, $\mathrm{PCB} 95_{\mathrm{lw}}, \mathrm{PCB} 99_{\mathrm{lw}}$ and 3HO-PCB180 were identified as significant predictors of fT4 (Table 3). The wet weight PCB serum levels were not identified as significant predictors for fT4.

Table 2. Linear regression analysis for fT4.

\begin{tabular}{|c|c|c|c|c|c|}
\hline \multirow[b]{2}{*}{ POP } & \multirow[b]{2}{*}{ Significance } & \multirow[b]{2}{*}{$\mathbf{R}^{2}$} & \multicolumn{3}{|c|}{ Linear Regression Model } \\
\hline & & & & $\beta(95 \% \mathrm{CI})$ & $p$ \\
\hline \multirow[t]{6}{*}{ PCB95 $_{\mathrm{lw}}$} & 0.024 & 0.072 & & & \\
\hline & & & Gender & $-0.024(-0.113-0.066)$ & 0.604 \\
\hline & & & Age & $-0.001(-0.004-0.003)$ & 0.754 \\
\hline & & & BMI & $0.007(0.002-0.012)$ & 0.004 \\
\hline & & & Smoking status & $0.041(-0.071-0.154)$ & 0.470 \\
\hline & & & PCB95 $5_{\mathrm{lw}}$ & $-0.299(-0.595-0.002)$ & 0.048 \\
\hline \multirow[t]{6}{*}{ PCB99 ${ }_{\mathrm{lw}}$} & 0.024 & 0.071 & & & \\
\hline & & & Gender & $-0.026(-0.116-0.064)$ & 0.566 \\
\hline & & & Age & $-0.003(-0.007-0.001)$ & 0.108 \\
\hline & & & BMI & $0.006(0.001-0.011)$ & 0.012 \\
\hline & & & Smoking status & $0.046(-0.066-0.158)$ & 0.421 \\
\hline & & & PCB99 $9_{\mathrm{lw}}$ & $0.143(0.000-0.285)$ & 0.049 \\
\hline \multirow[t]{6}{*}{ PCB149 ${ }_{\mathrm{lw}}$} & 0.017 & 0.076 & & & \\
\hline & & & Gender & $-0.030(-0.121-0.062)$ & 0.586 \\
\hline & & & Age & $-0.001(-0.005-0.004)$ & 0.720 \\
\hline & & & BMI & $0.006(0.002-0.011)$ & 0.009 \\
\hline & & & Smoking status & $0.046(-0.069-0.161)$ & 0.505 \\
\hline & & & PCB149 ${ }_{\mathrm{lw}}$ & $-0.248(-0.471-0.025)$ & 0.030 \\
\hline \multirow[t]{7}{*}{ 3НО-РСВ118 } & 0.002 & 0.112 & & & \\
\hline & & & Gender & $-0.024(-0.113-0.065)$ & 0.592 \\
\hline & & & Age & $0.001(-0.002-0.005)$ & 0.442 \\
\hline & & & BMI & $0.005(0.000-0.010)$ & 0.061 \\
\hline & & & Smoke & $0.060(-0.053-0.173)$ & 0.293 \\
\hline & & & Total lipids & $0.000(-0.001-0.000)$ & 0.024 \\
\hline & & & 3HO-PCB118 & $-0.147(-0.267-0.028)$ & 0.016 \\
\hline \multirow[t]{7}{*}{ 3НО-РСВ180 } & 0.003 & 0.110 & & & \\
\hline & & & Gender & $-0.041(-0.130-0.049)$ & 0.381 \\
\hline & & & Age & $-0.002(-0.007-0.002)$ & 0.257 \\
\hline & & & BMI & $0.010(0.005-0.015)$ & 0.000 \\
\hline & & & Smoke & $0.083(-0.030-0.196)$ & 0.148 \\
\hline & & & Total lipids & $0.000(-0.001-0.000)$ & 0.020 \\
\hline & & & 3НО-РCВ180 & $0.287(0.047-0.527)$ & 0.020 \\
\hline
\end{tabular}

The model with an OH-PCB level included gender, age, BMI, current smoking behavior, total lipids and one serum HO-PCB level. The model with a PCB level included age, BMI, current smoking behavior and one serum PCB level (expressed as lipid adjusted in ng/g lipids); fT4 was used as a square root transformed variable. All HO-PCB and PCB levels were used after log transformation. Representation is limited to these models with a significant contribution of a PCB or HO-PCB. For details on all models, please check Supplementary.

\subsection{Regression Analysis for TSH}

No PCB, either expressed as wet weight or lipid weight, or hydroxylated PCB metabolite could be identified as a significant predictor of TSH levels. 
Table 3. Forward stepwise regression analysis for fT4.

\begin{tabular}{ccc}
\hline Variable & B (95\%CI) & $\boldsymbol{P}$ \\
\hline Constant & $3.563(3.303-3.823)$ & $<0.001$ \\
Gender & $-0.015(-0.100-0.071)$ & 0.734 \\
Age & $-0.006(-0.011-0.002)$ & 0.007 \\
Current smoking & $-0.023(-0.069-0.023)$ & 0.321 \\
BMI & $0.007(0.001-0.012)$ & 0.013 \\
PCB95 & $-0.412(-0.763-0.061)$ & 0.022 \\
PCB99 & $0.309(0.143-0.474)$ & $<0.001$ \\
PCB149 & $-0.174(-0.470-0.122)$ & 0.248 \\
3HO-PCB118 & $-0.104(-0.233-0.025)$ & 0.114 \\
3HO-PCB180 & $0.251(0.008-0.494)$ & 0.043
\end{tabular}

The model included gender, age, current smoking behavior, BMI and total lipid levels, serum levels of 3HO-PCB118 and 3HO-PCB180, and PCB95 ${ }_{\mathrm{lw}}, \mathrm{PCB} 99_{\mathrm{lw}}$ and PCB149 ${ }_{\mathrm{lw}}$; fT4 was used as a square root transformed variable. All HO-PCB and PCB levels were used after log transformation.

\section{Discussion}

Polychlorinated biphenyls are suspected to disrupt endocrine balance, and in particular thyroid homeostasis. The mechanisms through which PCBs and their hydroxylated metabolites exert thyroid disruptive capacities have been unraveled in recent years, both in vitro and in animal studies [37]. PCBs are capable of interfering with thyroid hormone levels at many sites. At the DNA level, PCBs interfere with thyroid hormone receptor-mediated transcription [38]. Secondly, they affect synthesis associated proteins such as thyroid peroxidase [24]. In vitro, PCBs interfere with the sodium/iodide symporter [39] and compete with native hormone at the levels of transport protein $[40,41]$ and act as agonists at the level of the thyroid receptor $[42,43]$. PCBs also enhance the excretion of thyroid hormones in vitro and in rats [22,26]. Finally, in fish, PCBs interfere with several iodothyronine deiodinases [44]. These interactions offer an clarification for the reduced fT4 levels, but the pathophysiological mechanism(s) causing blunting of a compensatory TSH rise remain largely unexplained. One possible mechanism has been documented in rats, indicating high doses of PCBs can induce impaired TRH-induced TSH release at the pituitary level $[45,46]$. As opposed to data on PCBs, data on the action mechanisms of PCB metabolites are scarce, and are largely derived from in vitro data with few in vivo data. Hydroxylated PCB metabolites disrupt thyroglobulin synthesis and excretion [47] and display a weak affinity for the human thyroid receptor [41,48]. In vitro, inactivation of thyroid hormones is inhibited by OH-PCBs due to limiting of the sulfotransferase activity [49]. Hydroxylated PCBs also interfere with thyroid hormone receptor-mediated transcription [50]. Increased T4 accumulation in the liver, inducing decreased serum T4, has been reported [51]. To date, no interference of PCB metabolites with TRH or TSH secretion has been documented. The lipid solubility of PCB metabolites is slightly lower than that of PCBs, which could explain the mechanistic differences. It should be noted that all of the studies mentioned above describe responses on acutely administered doses of PCBs and PCB metabolites. However, in the human situation, there is a chronic exposure, resulting from both low-level intake and internal exposure. It is unclear if the human body is capable of certain adaptive mechanism, for example by inducing CYP450 enzymes.

Human studies have provided conflicting data on the exact nature of the resulting thyroid profile change. Our study aimed at investigating the relationship between serum levels of PCBs and, in particular, the hydroxylated PCB metabolites, with clinically available markers of thyroid function in an adult population.

To our knowledge, we are the first to report 3HO-PCB118 and 3HO-PCB180 as independent, significant predictors of fT4. 3HO-PCB180 is a metabolite of PCB180 and PCB172, while 3HO-PCB118 can be formed from PCB118, PCB126 and PCB107. PCB118, PCB180 and PCB172 were also measured in our sample, but their levels did not show a significant link with fT4. We did not measure both other mother compounds of 3HO-PCB118. Dallaire reported a negative relation between serum levels 
of HO-PCB199 and HO-PCB208 and TSH levels in an adult Inuit population, but it should be noted that the concentration of hydroxylated PCB metabolites in their study was about a tenfold higher than in our sample [52]. In the same study, seven HO-PCBs were associated with decreased total T3 concentration [52]. Hagmar et al. measured 4HO-PCB107 and 4HO-PCB187 in a female cohort, yet they do not report on the link between these PCB metabolites and thyroid function [53]. In Vietnamese women, several PCBs and HO-PCBs correlated with fT4, and PCB74 and PCB118 correlated negatively with TSH; in Vietnamese men only PCB138 and PCB153 correlated significantly with fT4 and no relation with TSH could be detected [54]. Our findings underscore the need for further research into the endocrine disrupting capacities of hydroxylated PCB metabolites.

When the different PCBs and PCB metabolites were analyzed individually, regression analysis indicates a significantly negative effect of $\mathrm{PCB} 95_{l_{\mathrm{w}}}$ and $\mathrm{PCB} 149_{\mathrm{lw}_{\mathrm{w}}}$, and a significantly positive effect of ${ }^{P C B} 99_{l w}$ on fT4 levels. Possibly as a consequence of these divergent influences, and the non-significant effect of most of the measured PCBs, the predictive effect of the sum of all PCBs was not significant in our population. The effect of PCBs on circulating levels of fT4 has been assessed by several previous studies. Free T4 was unaffected by levels of PCBs in several studies [53,55-57]. The study of Hagmar focused on PCB153, while all other studies analyze several PCB congeners. Concentrations of PCBs vary substantially between studies. In the studies focusing on participants with background exposure [52,58], concentrations of PCBs in our study are comparable. However, in studies focusing on participants with higher exposure levels, the PCB serum levels are up to an 8 fold higher compared to our study [53,55-57]. In the study of Langer et al., fT4 levels were increased in participants with higher PCB levels [37]. However, it should be noted that the population studied by Langer et al. consisted of people living in a heavily polluted area. Their PCB levels were an order of magnitude higher than the levels detected in our cohort and only the effect of the sum of all examined PCBs was explored. In this perspective, it is of particular interest that the effect of individual PCB compounds diverged in our study.

Our analyses indicate no effect of either PCBs or their hydroxylated metabolites on the TSH levels in our study sample. This is in line with the majority of the existing studies that did not detect a measurable influence on TSH levels [53,55,57-63]. The magnitude of PCB serum levels vary considerably between studies, as both groups with background exposure as groups with high exposure were studied. Most studies are limited to one gender [53,55-59,64]. It is somewhat puzzling that the remaining studies reported both increased and decreased TSH levels $[56,62,64-68]$. Four studies reported a decreased TSH with higher levels of PCBs, in 63 occupationally exposed men in the USA [56], in 89 women who miscarried in Germany [65], in 464 women and men in an industrially heavily polluted area of Slovakia [66] and in 545 fish consuming captains in the USA [67]. In a study by Turyk et al. [68] in 2445 American citizens with background exposure, influence on TSH levels was affected by age and gender, with a lower TSH in older men, and an elevated TSH in older women. Abdelouahab et al. detected no effect on TSH levels in Canadian women, while TSH levels were higher in fish consuming men with higher PCB levels [64].

When analyzing the different studies in humans, the difficulties in comparability are striking. First, the analytical techniques for PCBs and their metabolites differ, but most methods can accurately detect low levels. Secondly, often the sum of PCB congeners is used for analysis, but the number of measured PCB congeners differs between studies, as does the choice in International Union of Pure and Applied Chemistry (IUPAC) numbers. Thirdly, the analyzed media vary (serum, whole blood). Finally, some authors report wet weight data, while others use lipid-adjusted data. However, PCBs are capable of inducing dyslipidemia, even in the absence of obesity [69]. Disturbances in thyroid metabolism also give cause for lipid alterations. As such, using lipid-adjusted data to investigate the link between PCBs and thyroid metabolism may inadvertedly cause an overadjustment of reality. This caveat has recently been adverted by La Merril [70]. In this perspective, the significant influence of lipid adjusted PCB levels that were not reproducible with wet weight data, should be interpreted with caution. Hydroxylated PCB levels are, however, always reported as wet weight, due to their 
binding to proteins. As PCBs compete with thyroid hormone at the level of the transport protein in vitro, it is interesting to study this effect in vivo in men. However, since our study focused on TSH and fT4, without data on total T4 or total T3, this was not feasible. The available data on this topic show divergent result, with several studies reporting no effect on total $\mathrm{T} 4[53,55,56,59,61,64]$ or total T3 $[55,56,60,62,64]$. In Canadian and U.S. men with high PCB levels, total T4 is lower $[58,62,64]$, a result that was replicated in a study with 51 U.S. women [62] and in a mixed gender Spanish study group [63].

Additionally, it should also be noted that in vitro and animal testing to study the effects of PCBs is often undertaken using a single PCB congener. However, the complexity of human exposure is extensive, given the vast array of compounds to which humans are exposed simultaneously. The concentrations of endocrine disrupting chemicals are often closely intercorrelated, providing additional difficulty in determining which of the compounds have an effect. In our study, HO-PCB180 was the only PCB metabolite to retain its statistical significance after stepwise multiple regression, while the components PCB95 ${ }_{1 \mathrm{w}}$ and $\mathrm{PCB} 99_{\mathrm{lw}}$ also had statistical significance. As demonstrated by our results, grouping the levels of a certain class of chemicals might obscure the underlying opposing effects of individual compounds.

As mentioned previously, most studies have not been able to detect a link between TSH levels and PCB serum levels. PCBs are capable of inducing an impaired TSH response [46], but it has not yet been explored if hydroxylated PCBs possess such capacities. However, from a clinical point of view, TSH elevation or reduction is considered to be the hallmark of impaired thyroid function. Even if the distinction between subclinical and overt thyroid disease is somewhat arbitrary because it depends to a considerable extent on the position of the patient's normal set point for fT3 and fT4 within the laboratory reference range, subclinical hypo- and hyperthyroidism has been associated with increased, predominantly cardiovascular, morbidity [1,71]. Moreover, thyroid hormones are thought to exert a complex, though profound impact on several key components of the metabolic syndrome, such as weight control, blood pressure and glucose metabolism [72]. PCBs have been linked to the pandemic rise of obesity and associated diseases such as diabetes [73]. The possibility of an additional aggravating effect on these conditions through the thyroid system, certainly merits investigation. So although the effect of PCB and HO-PCB disturbance at the individual level might be small, the impact at population level, and its ensuing burden of disease and health care related costs, should be considered significant.

This study has some limitations. Assessment of ongoing exposure through intake of items such as contaminated food or ingestion of dust has not been performed in this study population. PCB serum levels are known to increase slowly with age and acutely during weight loss [33]. As this study is cross-sectional, no information was available on past fluctuations in serum levels. If these fluctuations could have an effect on thyroid hormone metabolism, remains unclear. From the current knowledge, the authors cannot rule out that an obese and/or diabetic participant metabolizes PCBs into hydroxylated PCB metabolites differently than a lean and/or non-diabetic participant. Given the cross-sectional design of our study, a causal link between the measured levels of PCB and PCB metabolites and thyroid hormone levels cannot be established. Other chemicals, such as polychlorinated dibenzodioxins or polychlorinateddibenzofurans might also have the in vitro potency to disrupt thyroid metabolism, but were not studied in our population [13].

Our study suggests PCBs and their metabolites are associated with lower levels of fT4, without a simultaneous rise in TSH. Given the limited effects on fT4 and the lack of compensatory TSH rise, it remains uncertain if these changes are clinically relevant. In the future, a prospective, longitudinal study, focusing on TSH, fT4 and fT3 would help to unravel to what extend PCBs and their metabolites are capable of disrupting circulating fT4 and fT3 hormone levels and inhibiting the compensatory rise in TSH normally triggered by fT4 and fT4 decline. It would be interesting to investigate if such inappropriately low TSH is caused by an impaired TRH-response, or caused by a change in local fT4/fT3 signaling at the target tissues. 


\section{Conclusions}

Our study indicates that in vivo, circulating fT4 levels can be linked to serum levels of several PCBs and hydroxylated PCB metabolites.These data add to the existing evidence that the endocrine disrupting capacities of PCBs and their metabolites can disrupt thyroid homeostasis.

Supplementary Materials: The following are available online at www.mdpi.com/1660-4601/13/4/421/s1, Table S1: PCB levels in serum $(n=180)$, Table S2: PCB metabolite levels in serum $(n=180)$, Table S3: Linear regression for FT4 with lipid adjusted PCBs, Table S4: Linear regression for FT4 with hydroxylated PCB metabolites and total lipids.

Acknowledgments: Alin C. Dirtu acknowledges a postdoctoral fellowship from the Research Scientific Foundation-Flanders (FWO). Nurses helping with sampling and handling are also acknowledged. The authors explicitly thank Kristien Wouters, statistician at the Antwerp University Hospital, for her statistical help. The project was funded by the University of Antwerp through a GOA project (FA020000/2/3565).

Author Contributions: Eveline Dirinck, Alin C. Dirtu, Philippe G. Jorens, Luc F. Van Gaal and Adrian Covaci conceptualized the study. Eveline Dirinck recruited the patient cohort, collected the clinical data and samples. Alin C. Dirtu, Govindan Malarvannan and Adrian Covaci analyzed the samples for PCBs and HO-PCBs. Eveline Dirinck, Alin C. Dirtu, Govindan Malarvannan and Adrian Covaci contributed to data interpretation. Eveline Dirinck led the literature search, data collection, statistical analysis, data interpretation, and writing of the report. All authors critically reviewed the manuscript and approved the final draft. Eveline Dirinck acts as guarantor for this manuscript.

Conflicts of Interest: The authors declare no conflict of interest.

\section{References}

1. Andersen, S.; Pedersen, K.M.; Bruun, N.H.; Laurberg, P. Narrow individual variations in serum $t(4)$ and $t(3)$ in normal subjects: A clue to the understanding of subclinical thyroid disease. J. Clin. Endocrinol. Metab. 2002, 87, 1068-1072. [CrossRef] [PubMed]

2. Bauer, M.; Goetz, T.; Glenn, T.; Whybrow, P.C. The thyroid-brain interaction in thyroid disorders and mood disorders. J. Neuroendocrinol. 2008, 20, 1101-1114. [CrossRef] [PubMed]

3. Kim, B. Thyroid hormone as a determinant of energy expenditure and the basal metabolic rate. Thyroid 2008, 18, 141-144. [CrossRef] [PubMed]

4. Kahapola-Arachchige, K.M.; Hadlow, N.; Wardrop, R.; Lim, E.M.; Walsh, J.P. Age-specific TSH reference ranges have minimal impact on the diagnosis of thyroid dysfunction. Clin. Endocrinol. (Oxf.) 2012, 77, 773-779. [CrossRef] [PubMed]

5. Vadiveloo, T.; Donnan, P.T.; Murphy, M.J.; Leese, G.P. Age- and gender-specific TSH reference intervals in people with no obvious thyroid disease in Tayside, Scotland: The thyroid epidemiology, audit, and research study (tears). J. Clin. Endocrinol. Metab. 2013, 98, 1147-1153. [CrossRef] [PubMed]

6. Kussmaul, T.; Greiser, K.H.; Haerting, J.; Werdan, K.; Thiery, J.; Kratzsch, J. Thyroid analytes tsh, ft3 and ft4 in serum of healthy elderly subjects as measured by the roche modular system: Do we need age and gender dependent reference levels? Clin. Lab. 2014, 60, 1551-1559. [PubMed]

7. Asvold, B.O.; Bjoro, T.; Vatten, L.J. Association of serum tsh with high body mass differs between smokers and never-smokers. J. Clin. Endocrinol. Metab. 2009, 94, 5023-5027. [CrossRef] [PubMed]

8. Belin, R.M.; Astor, B.C.; Powe, N.R.; Ladenson, P.W. Smoke exposure is associated with a lower prevalence of serum thyroid autoantibodies and thyrotropin concentration elevation and a higher prevalence of mild thyrotropin concentration suppression in the third national health and nutrition examination survey (NHANES III). J. Clin. Endocrinol. Metab. 2004, 89, 6077-6086. [PubMed]

9. Mehran, L.; Amouzgar, A.; Delshad, H.; Azizi, F. The association of cigarette smoking with serum TSH concentration and thyroperoxidase antibody. Exp. Clin. Endocrinol. Diabetes 2012, 120, 80-83. [CrossRef] [PubMed]

10. Asvold, B.O.; Bjoro, T.; Nilsen, T.I.; Vatten, L.J. Tobacco smoking and thyroid function: A population-based study. Arch. Intern. Med. 2007, 167, 1428-1432. [CrossRef] [PubMed]

11. Roef, G.; Lapauw, B.; Goemaere, S.; Zmierczak, H.G.; Toye, K.; Kaufman, J.M.; Taes, Y. Body composition and metabolic parameters are associated with variation in thyroid hormone levels among euthyroid young men. Eur. J. Endocrinol. 2012, 167, 719-726. [CrossRef] [PubMed] 
12. Asvold, B.O.; Vatten, L.J.; Nilsen, T.I.; Bjoro, T. The association between TSH within the reference range and serum lipid concentrations in a population-based study. The hunt study. Eur. J. Endocrinol. 2007, 156, 181-186. [CrossRef] [PubMed]

13. Boas, M.; Feldt-Rasmussen, U.; Main, K.M. Thyroid effects of endocrine disrupting chemicals. Mol. Cell. Endocrinol. 2012, 355, 240-248. [CrossRef] [PubMed]

14. Brucker-Davis, F. Effects of environmental synthetic chemicals on thyroid function. Thyroid 1998, 8, 827-856. [CrossRef] [PubMed]

15. Surks, M.I.; Ortiz, E.; Daniels, G.H.; Sawin, C.T.; Col, N.F.; Cobin, R.H.; Franklyn, J.A.; Hershman, J.M.; Burman, K.D.; Denke, M.A.; et al. Subclinical thyroid disease: Scientific review and guidelines for diagnosis and management. JAMA 2004, 291, 228-238. [CrossRef] [PubMed]

16. Nichols, B.R.; Hentz, K.L.; Aylward, L.; Hays, S.M.; Lamb, J.C. Age-specific reference ranges for polychlorinated biphenyls (PCB) based on the NHANES 2001-2002 survey. J. Toxicol. Environ. Health A 2007, 70, 1873-1877. [CrossRef] [PubMed]

17. Pelletier, C.; Imbeault, P.; Tremblay, A. Energy balance and pollution by organochlorines and polychlorinated biphenyls. Obes. Rev. 2003, 4, 17-24. [CrossRef] [PubMed]

18. Mrema, E.J.; Rubino, F.M.; Brambilla, G.; Moretto, A.; Tsatsakis, A.M.; Colosio, C. Persistent organochlorinated pesticides and mechanisms of their toxicity. Toxicology 2013, 307, 74-88. [CrossRef] [PubMed]

19. Grimm, F.A.; Hu, D.; Kania-Korwel, I.; Lehmler, H.J.; Ludewig, G.; Hornbuckle, K.C.; Duffel, M.W.; Bergman, A.; Robertson, L.W. Metabolism and metabolites of polychlorinated biphenyls. Crit. Rev. Toxicol. 2015, 45, 245-272. [CrossRef] [PubMed]

20. Letcher, R.J.; Klasson-Wehler, E.; Bergman, A. Methyl sulfone and hydroxylated metabolites of poylchlorinated biphenyls. Handb. Environ. Chem. 2000, 3, 315-359.

21. McKinney, J.D. Multifunctional receptor model for dioxin and related compound toxic action: Possible thyroid hormone-responsive effector-linked site. Environ. Health Perspect. 1989, 82, 323-336. [CrossRef] [PubMed]

22. Hallgren, S.; Darnerud, P.O. Polybrominated diphenyl ethers (PBDEs), polychlorinated biphenyls (PCBs) and chlorinated paraffins (CPs) in rats-testing interactions and mechanisms for thyroid hormone effects. Toxicology 2002, 177, 227-243. [CrossRef]

23. Hallgren, S.; Sinjari, T.; Hakansson, H.; Darnerud, P.O. Effects of polybrominated diphenyl ethers (PBDEs) and polychlorinated biphenyls (PCBs) on thyroid hormone and vitamin A levels in rats and mice. Arch. Toxicol. 2001, 75, 200-208. [CrossRef] [PubMed]

24. Liu, C.; Wang, C.; Yan, M.; Quan, C.; Zhou, J.; Yang, K. Pcb153 disrupts thyroid hormone homeostasis by affecting its biosynthesis, biotransformation, feedback regulation, and metabolism. Horm. Metab. Res. 2012, 44, 662-669. [CrossRef] [PubMed]

25. Tang, J.M.; Li, W.; Xie, Y.C.; Guo, H.W.; Cheng, P.; Chen, H.H.; Zheng, X.Q.; Jiang, L.; Cui, D.; Liu, Y.; et al. Morphological and functional deterioration of the rat thyroid following chronic exposure to low-dose PCB118. Exp. Toxicol. Pathol. 2013, 65, 989-994. [CrossRef] [PubMed]

26. Fisher, J.W.; Campbell, J.; Muralidhara, S.; Bruckner, J.V.; Ferguson, D.; Mumtaz, M.; Harmon, B.; Hedge, J.M.; Crofton, K.M.; Kim, H.; et al. Effect of PCB 126 on hepatic metabolism of thyroxine and perturbations in the hypothalamic-pituitary-thyroid axis in the rat. Toxicol. Sci. 2006, 90, 87-95. [CrossRef] [PubMed]

27. Hood, A.; Hashmi, R.; Klaassen, C.D. Effects of microsomal enzyme inducers on thyroid-follicular cell proliferation, hyperplasia, and hypertrophy. Toxicol. Appl. Pharmacol. 1999, 160, 163-170. [CrossRef] [PubMed]

28. Van der Plas, S.A.; Lutkeschipholt, I.; Spenkelink, B.; Brouwer, A. Effects of subchronic exposure to complex mixtures of dioxin-like and non-dioxin-like polyhalogenated aromatic compounds on thyroid hormone and vitamin A levels in female sprague-dawley rats. Toxicol. Sci. 2001, 59, 92-100. [CrossRef] [PubMed]

29. Dallaire, R.; Muckle, G.; Dewailly, E.; Jacobson, S.W.; Jacobson, J.L.; Sandanger, T.M.; Sandau, C.D.; Ayotte, P. Thyroid hormone levels of pregnant Inuit women and their infants exposed to environmental contaminants. Environ. Health Perspect. 2009, 117, 1014-1020. [CrossRef] [PubMed]

30. Bechaux, C.; Zeilmaker, M.; Merlo, M.; Bokkers, B.; Crepet, A. An integrative risk assessment approach for persistent chemicals: A case study on dioxins, furans and dioxin-like PCBs in france. Regul. Toxicol. Pharmacol. 2014, 70, 261-269. [CrossRef] [PubMed]

31. Wild, D. The Immunoassay Handbook, 4th ed.; Elsevier: Amsterdam, The Netherlands, 2004. 
32. DeVito, M.; Biegel, L.; Brouwer, A.; Brown, S.; Brucker-Davis, F.; Cheek, A.O.; Christensen, R.; Colborn, T.; Cooke, P.; Crissman, J.; et al. Screening methods for thyroid hormone disruptors. Environ. Health Perspect. 1999, 107, 407-415. [CrossRef] [PubMed]

33. Dirtu, A.C.; Dirinck, E.; Malarvannan, G.; Neels, H.; Van Gaal, L.; Jorens, P.G.; Covaci, A. Dynamics of organohalogenated contaminants in human serum from obese individuals during one year of weight loss treatment. Environ. Sci. Technol. 2013, 47, 12441-12449. [CrossRef] [PubMed]

34. Phillips, D.L.; Pirkle, J.L.; Burse, V.W.; Bernert, J.T., Jr.; Henderson, L.O.; Needham, L.L. Chlorinated hydrocarbon levels in human serum: Effects of fasting and feeding. Arch. Environ. Contam. Toxicol. 1989, 18, 495-500. [CrossRef] [PubMed]

35. Voorspoels, S.; Covaci, A.; Maervoet, J.; Schepens, P. Relationship between age and levels of organochlorine contaminants in human serum of a belgian population. Bull. Environ. Contam Toxicol. 2002, 69, 22-29. [CrossRef] [PubMed]

36. Palma, C.C.; Pavesi, M.; Nogueira, V.G.; Clemente, E.L.; Vasconcellos, M.D.; Pereira, L.C.J.; Pacheco, F.F.; Braga, T.G.; Bello, L.D.; Soares, J.O.; et al. Prevalence of thyroid dysfunction in patients with diabetes mellitus. Diabetol. Metab. Syndr. 2013, 5, 58. [CrossRef] [PubMed]

37. Langer, P.; Tajtakova, M.; Kocan, A.; Drobna, B.; Kostalova, L.; Fodor, G.; Klimes, I. Thyroid volume, iodine intake, autoimmune thyroid disorders, inborn factors, and endocrine disruptors: Twenty-year studies of multiple effects puzzle in Slovakia. Endocr. Regul. 2012, 46, 191-203. [CrossRef] [PubMed]

38. Miyazaki, W.; Iwasaki, T.; Takeshita, A.; Kuroda, Y.; Koibuchi, N. Polychlorinated biphenyls suppress thyroid hormone receptor-mediated transcription through a novel mechanism. J. Biol. Chem. 2004, 279, 18195-18202. [CrossRef] [PubMed]

39. Yang, H.; Chen, H.; Guo, H.; Li, W.; Tang, J.; Xu, B.; Sun, M.; Ding, G.; Jiang, L.; Cui, D.; et al. Molecular mechanisms of 2, 3', 4, 4', 5-pentachlorobiphenyl-induced thyroid dysfunction in frtl-5 cells. PLoS ONE 2015, 10, e0120133. [CrossRef] [PubMed]

40. Chauhan, K.R.; Kodavanti, P.R.; McKinney, J.D. Assessing the role of ortho-substitution on polychlorinated biphenyl binding to transthyretin, a thyroxine transport protein. Toxicol. Appl. Pharmacol. 2000, 162, 10-21. [CrossRef] [PubMed]

41. Cheek, A.O.; Kow, K.; Chen, J.; McLachlan, J.A. Potential mechanisms of thyroid disruption in humans: Interaction of organochlorine compounds with thyroid receptor, transthyretin, and thyroid-binding globulin. Environ. Health Perspect. 1999, 107, 273-278. [CrossRef] [PubMed]

42. Fritsche, E.; Cline, J.E.; Nguyen, N.H.; Scanlan, T.S.; Abel, J. Polychlorinated biphenyls disturb differentiation of normal human neural progenitor cells: Clue for involvement of thyroid hormone receptors. Environ. Health Perspect. 2005, 113, 871-876. [CrossRef] [PubMed]

43. Gauger, K.J.; Giera, S.; Sharlin, D.S.; Bansal, R.; Iannacone, E.; Zoeller, R.T. Polychlorinated biphenyls 105 and 118 form thyroid hormone receptor agonists after cytochrome p4501a1 activation in rat pituitary gh3 cells. Environ. Health Perspect. 2007, 115, 1623-1630. [CrossRef] [PubMed]

44. Dong, Y.; Tian, H.; Wang, W.; Zhang, X.; Liu, J.; Ru, S. Disruption of the thyroid system by the thyroid-disrupting compound aroclor 1254 in juvenile Japanese flounder (Paralichthys olivaceus). PLoS ONE 2014, 9, e104196. [CrossRef] [PubMed]

45. Hood, A.; Klaassen, C.D. Differential effects of microsomal enzyme inducers on in vitro thyroxine $(\mathrm{t}(4))$ and triiodothyronine $(t(3))$ glucuronidation. Toxicol. Sci. 2000, 55, 78-84. [CrossRef] [PubMed]

46. Khan, M.A.; Hansen, L.G. Ortho-substituted polychlorinated biphenyl (PCB) congeners (95 or 101) decrease pituitary response to thyrotropin releasing hormone. Toxicol. Lett. 2003, 144, 173-182. [CrossRef]

47. Yang, F.; Xu, Y.; Pan, H.; Wu, D. Induction of hepatic cytochrome p4501a1/2b activity and disruption of thyroglobulin synthesis/secretion by mono-ortho polychlorinated biphenyl and its hydroxylated metabolites in rat cell lines. Environ. Toxicol. Chem. 2008, 27, 220-225. [CrossRef] [PubMed]

48. Lans, M.C.; Spiertz, C.; Brouwer, A.; Koeman, J.H. Different competition of thyroxine binding to transthyretin and thyroxine-binding globulin by hydroxy-PCBs, PCDDs and PCDFs. Eur. J. Pharmacol. 1994, 270, 129-136. [CrossRef]

49. Schuur, A.G.; Brouwer, A.; Bergman, A.; Coughtrie, M.W.; Visser, T.J. Inhibition of thyroid hormone sulfation by hydroxylated metabolites of polychlorinated biphenyls. Chem. Biol. Interact. 1998, 109, 293-297. [CrossRef] 
50. Amano, I.; Miyazaki, W.; Iwasaki, T.; Shimokawa, N.; Koibuchi, N. The effect of hydroxylated polychlorinated biphenyl (oh-PCB) on thyroid hormone receptor (tr)-mediated transcription through native-thyroid hormone response element (TRE). Ind. Health 2010, 48, 115-118. [CrossRef] [PubMed]

51. Kato, Y.; Haraguchi, K.; Kubota, M.; Seto, Y.; Ikushiro, S.; Sakaki, T.; Koga, N.; Yamada, S.; Degawa, M. 4-hydroxy-2, 2', 3, 4', 5, 5', 6-heptachlorobiphenyl-mediated decrease in serum thyroxine level in mice occurs through increase in accumulation of thyroxine in the liver. Drug Metab. Dispos. 2009, 37, 2095-2102. [CrossRef] [PubMed]

52. Dallaire, R.; Dewailly, E.; Pereg, D.; Dery, S.; Ayotte, P. Thyroid function and plasma concentrations of polyhalogenated compounds in Inuit adults. Environ. Health Perspect. 2009, 117, 1380-1386. [CrossRef] [PubMed]

53. Hagmar, L.; Rylander, L.; Dyremark, E.; Klasson-Wehler, E.; Erfurth, E.M. Plasma concentrations of persistent organochlorines in relation to thyrotropin and thyroid hormone levels in women. Int. Arch. Occup. Environ. Health 2001, 74, 184-188. [CrossRef] [PubMed]

54. Eguchi, A.; Nomiyama, K.; Minh Tue, N.; Trang, P.T.; Hung Viet, P.; Takahashi, S.; Tanabe, S. Residue profiles of organohalogen compounds in human serum from e-waste recycling sites in North Vietnam: Association with thyroid hormone levels. Environ. Res. 2015, 137, 440-449. [CrossRef] [PubMed]

55. Hagmar, L.; Bjork, J.; Sjodin, A.; Bergman, A.; Erfurth, E.M. Plasma levels of persistent organohalogens and hormone levels in adult male humans. Arch. Environ. Health 2001, 56, 138-143. [CrossRef] [PubMed]

56. Persky, V.; Piorkowski, J.; Turyk, M.; Freels, S.; Chatterton, R., Jr.; Dimos, J.; Bradlow, H.L.; Chary, L.K.; Burse, V.; Unterman, T.; et al. Polychlorinated biphenyl exposure, diabetes and endogenous hormones: A cross-sectional study in men previously employed at a capacitor manufacturing plant. Environ. Health 2012, 11, 57. [CrossRef] [PubMed]

57. Rylander, L.; Wallin, E.; Jonssson, B.A.; Stridsberg, M.; Erfurth, E.M.; Hagmar, L. Associations between cb-153 and p,p'-dde and hormone levels in serum in middle-aged and elderly men. Chemosphere 2006, 65, 375-381. [CrossRef] [PubMed]

58. Meeker, J.D.; Altshul, L.; Hauser, R. Serum pcbs, p,p'-dde and hcb predict thyroid hormone levels in men. Environ. Res. 2007, 104, 296-304. [CrossRef] [PubMed]

59. Bloom, M.S.; Weiner, J.M.; Vena, J.E.; Beehler, G.P. Exploring associations between serum levels of select organochlorines and thyroxine in a sample of new york state sportsmen: The new york state angler cohort study. Environ. Res. 2003, 93, 52-66. [CrossRef]

60. Langer, P.; Kocan, A.; Tajtakova, M.; Radikova, Z.; Petrik, J.; Koska, J.; Ksinantova, L.; Imrich, R.; Huckova, M.; Chovancova, J.; et al. Possible effects of persistent organochlorinated pollutants cocktail on thyroid hormone levels and pituitary-thyroid interrelations. Chemosphere 2007, 70, 110-118. [CrossRef] [PubMed]

61. Langer, P.; Tajtakova, M.; Fodor, G.; Kocan, A.; Bohov, P.; Michalek, J.; Kreze, A. Increased thyroid volume and prevalence of thyroid disorders in an area heavily polluted by polychlorinated biphenyls. Eur. J. Endocrinol. 1998, 139, 402-409. [CrossRef] [PubMed]

62. Persky, V.; Turyk, M.; Anderson, H.A.; Hanrahan, L.P.; Falk, C.; Steenport, D.N.; Chatterton, R., Jr.; Freels, S. The effects of PCB exposure and fish consumption on endogenous hormones. Environ. Health Perspect. 2001, 109, 1275-1283. [CrossRef] [PubMed]

63. Sala, M.; Sunyer, J.; Herrero, C.; To-Figueras, J.; Grimalt, J. Association between serum concentrations of hexachlorobenzene and polychlorobiphenyls with thyroid hormone and liver enzymes in a sample of the general population. Occup. Environ. Med. 2001, 58, 172-177. [CrossRef] [PubMed]

64. Abdelouahab, N.; Mergler, D.; Takser, L.; Vanier, C.; St-Jean, M.; Baldwin, M.; Spear, P.A.; Chan, H.M. Gender differences in the effects of organochlorines, mercury, and lead on thyroid hormone levels in lakeside communities of Quebec (Canada). Environ. Res. 2008, 107, 380-392. [CrossRef] [PubMed]

65. Gerhard, I.; Daniel, V.; Link, S.; Monga, B.; Runnebaum, B. Chlorinated hydrocarbons in women with repeated miscarriages. Environ. Health Perspect. 1998, 106, 675-681. [CrossRef] [PubMed]

66. Langer, P.; Kocan, A.; Tajtakova, M.; Petrik, J.; Chovancova, J.; Drobna, B.; Jursa, S.; Pavuk, M.; Trnovec, T.; Sebokova, E.; et al. Human thyroid in the population exposed to high environmental pollution by organochlorinated pollutants for several decades. Endocr. Regul. 2005, 39, 13-20. [PubMed]

67. Turyk, M.E.; Anderson, H.A.; Freels, S.; Chatterton, R., Jr.; Needham, L.L.; Patterson, D.G., Jr.; Steenport, D.N.; Knobeloch, L.; Imm, P.; Persky, V.W. Associations of organochlorines with endogenous hormones in male great lakes fish consumers and nonconsumers. Environ. Res. 2006, 102, 299-307. [CrossRef] [PubMed] 
68. Turyk, M.E.; Anderson, H.A.; Persky, V.W. Relationships of thyroid hormones with polychlorinated biphenyls, dioxins, furans, and dde in adults. Environ. Health Perspect. 2007, 115, 1197-1203. [CrossRef] [PubMed]

69. Dalton, T.P.; Kerzee, J.K.; Wang, B.; Miller, M.; Dieter, M.Z.; Lorenz, J.N.; Shertzer, H.G.; Nerbert, D.W.; Puga, A. Dioxin exposure is an environmental risk factor for ischemic heart disease. Cardiovasc. Toxicol. 2001, 1, 285-298. [CrossRef]

70. La Merrill, M.; Emond, C.; Kim, M.J.; Antignac, J.P.; Le Bizec, B.; Clement, K.; Birnbaum, L.S.; Barouki, R. Toxicological function of adipose tissue: Focus on persistent organic pollutants. Environ. Health Perspect. 2013, 121, 162-169. [PubMed]

71. Rodondi, N.; den Elzen, W.P.; Bauer, D.C.; Cappola, A.R.; Razvi, S.; Walsh, J.P.; Asvold, B.O.; Iervasi, G.; Imaizumi, M.; Collet, T.H.; et al. Subclinical hypothyroidism and the risk of coronary heart disease and mortality. JAMA 2010, 304, 1365-1374. [CrossRef] [PubMed]

72. Iwen, K.A.; Schroder, E.; Brabant, G. Thyroid hormones and the metabolic syndrome. Eur. Thyroid. J. 2013, 2, 83-92. [CrossRef] [PubMed]

73. Dirinck, E.L.; Dirtu, A.C.; Govindan, M.; Covaci, A.; Van Gaal, L.F.; Jorens, P.G. Exposure to persistent organic pollutants: Relationship with abnormal glucose metabolism and visceral adiposity. Diabetes Care 2014, 37, 1951-1958. [CrossRef] [PubMed]

(C) 2016 by the authors; licensee MDPI, Basel, Switzerland. This article is an open access article distributed under the terms and conditions of the Creative Commons Attribution (CC-BY) license (http:/ / creativecommons.org/licenses/by/4.0/). 